\title{
Encountering Colonial Worlds Through Missionary Maps in the Late-Nineteenth- Century Grand Duchy of Finland
}

\section{Skurnik, Johanna Emilia}

Palgrave Macmillan

2021

Skurnik , J E 2021, Encountering Colonial Worlds Through Missionary Maps in the Late-Nineteenth- Century Grand Duchy of Finland . in R Merivirta , L Koivunen \& T Särkkä (eds), Finnish Colonial Encounters : From Anti-Imperialism to Cultural Colonialism and Complicity . Cambridge Imperial and Post-Colonial Studies, Palgrave Macmillan, Cham , pp. 199-222 . https://doi.org/10.1007/978-3-030-80610-1_8

http://hdl.handle.net/10138/340891

https://doi.org/10.1007/978-3-030-80610-1_8

cc_by

publishedVersion

Downloaded from Helda, University of Helsinki institutional repository.

This is an electronic reprint of the original article.

This reprint may differ from the original in pagination and typographic detail.

Please cite the original version. 


\title{
Encountering Colonial Worlds Through Missionary Maps in the Late-Nineteenth- Century Grand Duchy of Finland
}

\author{
Johanna Skurnik
}

The Finnish Missionary Society (FMS), founded in Helsinki in 1859, quickly made its presence known in different parts of the country through its printed materials. These included the publication of two periodicals, in Finnish and in Swedish, as well as two missionary world maps in Finnish (Maailman kartta Lähetys-Toimesta, Fig. 8.1) and in Swedish (Werldskarta öfver hedna-missionen). These maps visualized differentiations among peoples according to religion, with white areas marking Christians, gray Muslims, and black "heathens". Due to their wide circulation, affordable price, and bilingual capacity, these maps provided new means of engagement with world geographies for Finnish audiences. Moreover, they formed part of the cultural labor performed by Western missionary societies "at home", through writing, exhibitions, and public lectures; these

\footnotetext{
J. Skurnik $(\bowtie)$

Department of Philosophy, History and Art Studies, University of Helsinki, Helsinki, Finland

e-mail: johanna.skurnik@helsinki.fi

(C) The Author(s), under exclusive license to Springer Nature Switzerland AG 2021

R. Merivirta et al. (eds.), Finnish Colonial Encounters, Cambridge Imperial and Post-Colonial Studies, https://doi.org/10.1007/978-3-030-80610-1_8
} 


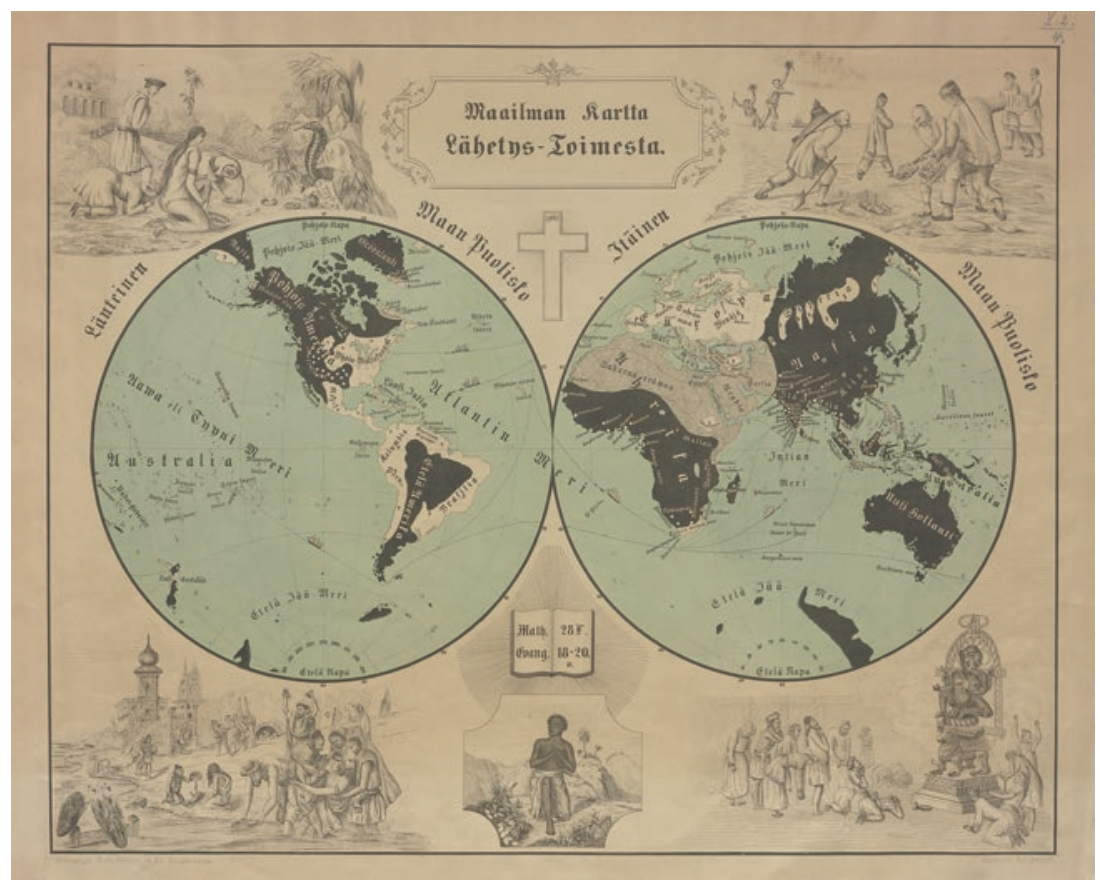

Fig. 8.1 The world map published by the Finnish Missionary Society beginning in 1859 became a popular print product in the Grand Duchy of Finland, going through several editions both in Finnish (pictured here) and in Swedish. Maailman kartta lähetys-toimesta, Finnish Missionary Society, circa 1860, Map Collection of the National Library of Finland. Published by permission of the National Library of Finland

helped generate, as Karen Vallgårda puts it, "an obligation towards the supposedly backward and uncivilised world" and "nurtured ideological justification of colonial rule" ${ }^{1}$ Considering that Western missionary enterprise combined aspects of spreading the gospel and civilizing the "heathens" in regions which were under the influence of various European colonial projects, it is pertinent to ask what kind of colonial encounters were facilitated by the maps and periodicals for Finnish audiences: how and why?

\footnotetext{
${ }^{1}$ Vallgårda 2016, 875-76.
} 
While existing scholarship on the FMS has identified the popularity of the maps in the Finnish context, they have not received in-depth critical attention. ${ }^{2}$ In this chapter I examine ways in which the FMS made use of the maps and other published materials to fuel "geographical imaginations" which were entangled with the colonial order. I conceptualize "geographical imaginations" as the ability of individuals and groups to define and imagine spaces and places and to relate to them. It is concerned with peoples' ideas of spatial and social reality that intertwine with the material world - in essence their mental images of the world. ${ }^{3}$ The FMS's conceptualization of the world as a space for missionary work was built into the maps, and the FMS utilized them to gain support for their cause. Simultaneously, the FMS operationalized the geographical imaginations to generate a sense of shared social identity in the world. Consequently, the FMS's publishing practices shaped the cognitive processes which affected how Finnish audiences encountered colonial worlds and colonial forms of knowledge through print. In this chapter I show how this occurred as the FMS adapted the map to a Finnish context and translated material from foreign periodicals that reported the proceedings of mainly British and German missionaries in colonial contexts. In so doing, the FMS was participating in the transnational circulation of forms of knowledge that can be conceptualized as "colonial". These were knowledges that Tony Ballantyne has defined as ones that were "produced out of and enabled resource exploitation, commerce, conquest and colonization", and had cultural, political, and economic significance. ${ }^{4}$ I also consider the implications of sending the first foreign mission to present-day northern Namibia in 1868; in that it allowed Finns to participate in the construction of "Ovamboland" as a space for European action.

The publication of missionary world maps was not unique to Finland. Throughout the nineteenth century, similar mass-produced maps reached the hands of readers in the Nordic countries as well as in central Europe, Great Britain, and North America. Maps visualizing the geography of the missionary field were published as portable sheet maps, bound up with booklets and as large wall maps. They decorated the meeting rooms of missionary societies and were used in Sunday schools. The maps shaped

${ }^{2}$ Paunu 1909, 14; Remes 1993, 33; Löytty 2006, 42; Löytty 2007, 266.

${ }^{3}$ My definition of "geographical imaginations" is based on Gregory 1994; Massey 2005; Gieseking 2017.

${ }^{4}$ Ballantyne 2007, 177. 
and conditioned the missionary outlook on the world and helped identify and dream of new fields for missions. Despite their prominent position, systematic research on this type of missionary cartography is only beginning. ${ }^{5}$ These maps warrant our attention because-together with other promotional materials directed at home audiences-they were part of the transnational construction of a shared moral responsibility for distant strangers. ${ }^{6}$ The maps' meanings were furthermore constructed in tandem with the ethnographic knowledges that the missionaries from different countries transmitted "home" from their fields of work, and which were often among the earliest ethnographic and geographical accounts of the still relatively unknown non-European world. ${ }^{7}$

The circulation of these knowledges entangled Finnish missionaries' imaginaries of the world with those of colonial philanthropists. ${ }^{8}$ In essence, the FMS materials sold Finnish audiences an idea of the potential progress of European civilization across the globe, not only by juxtaposing the "Self" against exotic and racialized "Others" but also by spatializing these encounters, thus effectively participating in what Edward Said has famously termed the "struggle over geography". Here peoples' relationships with land are not only about "soldiers and cannons but also about ideas, about forms, about images and imaginings". ${ }^{9}$ The missionaries made use of cartographic techniques to solidify their ideas as to how human variety, global geography, and spaces of concern were intertwined. In this sense, the Finnish printed materials made them an intrinsic part of the globalization of ideas of Western modernity, in which the missionary societies also shared. ${ }^{10}$ The initial lack of missionary fields of their own (or of overseas subjects in need of conversion), however, meant that Finns relied on communicating (colonial) knowledges gathered by other actors and relaying them to Finnish audiences in adapted forms.

In my exploration of the lifespans and functioning of the FMS maps, I pay close attention to their position in the transnational missionary

\footnotetext{
${ }^{5}$ See thematic issue of Cartographica Helvetica, "Missionskartographie" 2019; Onnekink 2020. The only extensive analysis of Finnish Missionary Society's cartographic activities remains Kokkonen 1993.

${ }^{6}$ For the other materials see Barringer 2004; Brewer 2005; Johnston 2005; Jensz and Acke 2013.

${ }^{7}$ Johnston 2005, 42; Nielssen et al. 2011, 6 .

${ }^{8}$ For colonial philanthropists, see Lambert and Lester 2004.

${ }^{9}$ Said 1993, 6.

${ }^{10}$ Dunch 2002.
} 
networks. As noted by Hilde Nielssen, Inger Marie Okkenhaug, and Karina Hestad Skeie, the "mobilisation of Christians across national borders and continents" was "unified by a common vision of a Christian empire". ${ }^{11}$ In analyzing the uses and purposes of the maps in a Finnish context, however, I also consider the local meanings and effects of the maps. In what follows, I critically compare the Finnish maps to their international counterparts. I focus on the years 1859-1895, during which the maps were published, and seek to understand the maps' intended uses through the relevant textual material, including the FMS's monthly missionary periodicals published in Finnish and Swedish (Suomen Lähetyssanomia (SL) and Missions-Tidning för Finland (MT)). The content of the periodicals was similar but not entirely identical, as they had different editors and were printed in different locations. ${ }^{12}$ During the first years the circulation of the periodicals varied between 2000 and 3000, which was enough to place them among the biggest magazines published. ${ }^{13}$ I also analyze the booklets which were published specifically to explain the maps. These included a booklet, the "explanation" of the map, which described the content and symbols of the maps one place at a time. ${ }^{14}$ They also included another booklet, titled Ewankelinen Lähetys, which connected the map to the aims and means of missionary work and explained the state of religion in different parts of the globe. ${ }^{15}$ By focusing on materials widely available in the public sphere, I explore the different types of meanings the FMS communicated in placing the maps in the hands of its Finnish audiences.

\section{Touring the World for Transformation}

The Finnish Missionary Society was established at a time when the missionary cause was transforming from sporadic efforts into a global endeavor. The production of the map immediately after establishment of the FMS, and its extensive distribution across the Grand Duchy, evince the

\footnotetext{
${ }^{11}$ Nielssen et al. 2011, 1 .

${ }^{12}$ Klemens J. G. Sirelius edited the MT until 1877, and Gustaf Dahlberg the SL until 1876, followed by Carl G. Töttermann for both periodicals.

${ }^{13}$ Gustafsson 2003, 78.

${ }^{14}$ The first editions of Selitys Lähetys-Toimen Kartalle and Beskrifning till Karta öfwer Hednamissionen were published in 1859 and the last, the fourteenth edition of the Finnish version, appeared in 1894.

${ }^{15}$ Ewankelinen Lähetys: Huntawa Ä̈̈ni Kristikunnalle 1861.
} 
world maps' instrumentality in procuring funds for Finnish missionary work. The first editions of the maps added up to a total of 10,000 and 5000 maps, the Finnish edition being the larger. They were sold for the price of ten silver kopeks, subsequently for 40 or 50 Finnish pennies. The maps could be obtained across the Grand Duchy through post offices, through FMS agents, or by ordering them from a bookstore in Helsinki. The maps quickly gained popularity and proved to have a long life cycle. The Finnish map had to be reprinted already the following year; some thirty years later, in 1894, a revised edition was still being printed. In total, between the first edition and those printed in the 1890s, the FMS put in circulation approximately 78,000 copies of the map. This occurred during a time the Finnish population was growing rapidly: from 1.7 million in 1859 to 2.7 million in $1900 .{ }^{16}$ Compact in size, the maps could easily be pinned to a wall or unfolded even on a small table. With only the key place names visible and most printed in a relatively large font, these maps provided an ideal form of visual engagement even with illiterate people. The maps thus helped their users in "denying space" and-almost literallyholding the world in their hands. ${ }^{17}$

The origins of the use of a cartographic medium to depict the global scope of the mission charge are not entirely clear, but a popular account of the first map of this type refers to William Carey, who founded the Baptist Missionary Society in 1792 in Britain. Carey, an English shoemaker and a teacher, is said to have drawn a map of the world on several sheets of paper, and-on the basis of quantitative information concerning the religions of different populations - to have colored heathen lands black. ${ }^{18}$ Carey also published a treatise discussing the Christian obligation for missionary work, which relied extensively on statistics and demographic argumentation and connected the idea of populations and religions. Martin Petzke has suggested that this marked a quantification of "heathens" as countable individuals, which helped fuel Christian missions into a global project. ${ }^{19}$ The thematic mappings used by many missionary societies proceeded along similar lines: the maps portrayed the geographical extent of different religions and plotted the positions of missionary stations. By the

\footnotetext{
${ }^{16}$ The numbers for the copies printed derive from the FMS's annual reports, published in the FMS periodicals between 1859 and 1895 .

${ }^{17}$ Compare Edney's conceptualization of the act of reading maps of distant places. Edney 2003.

${ }^{18}$ Onnekink 2020, 4.

${ }^{19}$ Petzke 2018, 190-92.
} 
time the FMS map was published in Finland, many versions of maps showing the extent of the missionary field were in circulation, for the use of children, adults, and specialists. ${ }^{20}$

The maps produced for Finnish audiences resembled those produced for children: they were plain in style and included illustrations. As an illustrated map the missionary map of the world stood out from other world maps available in Finland at the time, and the Finnish map was also a rarity due to its language: the first Finnish-language map of the world had been published (as a newspaper supplement) only a little over a decade earlier, in $1845 .{ }^{21}$ Popular missionary maps, especially those used for promotional purposes, routinely included illustrations. The model for the FMS map was a similar map published by the Basel Mission (Die Evangelische Missionsgesellschaft in Basel) circa 1845. ${ }^{22}$ The Basel map had been created by Godefroy Engelmann, a pioneer of lithography and chromolithography, a technique that allowed printing multi-color prints from stone. The FMS map and the Basel map resemble each other in their general layout, in the design of the cartouche, and in some of the illustrations. ${ }^{23}$ The FMS was not alone in following the model set by the Basel Mission; In the Swedish town of Lund, for example, the lithographer Magnus Körner printed maps that followed that of the Basel Mission in all its details. ${ }^{24}$

The main difference between the Basel map and the FMS map is in the illustrations bordering the map. The Finnish map includes four scenes relating to Asia, one in each corner; a kneeling African man, his hands crossed in prayer, is depicted at the bottom, between the two hemispheres. Above the African man we find an open Bible, with references to the

\footnotetext{
${ }^{20}$ Children's missionary map of the world, 1844, Maps CC.5.a.161, British Library map collection, The British Library, London, UK; Missions-Weltkarte für Jung und Alt, 1845, GE D-12545, département Cartes et plans, Bibliothèque nationale de France (hereafter BnF), Paris, France, https://catalogue.bnf.fr/ark:/12148/cb407532349; Weltkarte mit Angabe der protestantischen Missions-Anstalten und der Wichtigsten Schiffuhatscourse, 1852, GE C-8714, BnF. https://catalogue.bnf.fr/ark:/12148/cb407532391.

${ }^{21}$ The map accompanied an article on world geography published in Lukemisia Kansan Hyödyksi 1845, edited by Paavo Tikkanen.

22 "Kotomaalta," SL, 1869, no 10, 148. See Remes 1993, 33.

${ }^{23}$ Weltkarte der Mission, 1845, KARVAR-31.082, BMArchives, Basel Mission/Mission 21, Basel, Switzerland. https://www.bmarchives.org/items/show/100204633.

${ }^{24}$ Compare Weltkarte der Mission, 1845, KARVAR-31.082, BMArchives and Missionskarta öfver werlden, n.d., Blm 4567 2, Blekinge Museum, Karlskrona, Sweden. https://blm. kulturhotell.se/items/show/25159.
} 
proselytizing charge in the Gospel of St. Matthew, along with a cross beneath the cartouche. The geographical focus of the illustrations thus differs from that of the Basel map, which depicts a variety of peoples from across the world (North America, northern Scandinavia, China, India, Africa). ${ }^{25}$ The FMS may have used the Basel map as the model for the African man, an image also printed in British maps. ${ }^{26}$ The other illustrations were probably made following other foreign models; two of them coincide with illustrations on John Gilbert's Pictorial Missionary Map of the World, and on the Swedish adaptation of the same map. These are the top-right "Chinese scene", showing people burying a baby alive, and the bottom-left scene from India with people pouring water into the mouth of a man in the river Ganges. However, as Gilbert's map was published only in 1861, the illustrations must have been copied from elsewhere, perhaps a periodical; I have not been able to identify the specific source. ${ }^{27}$ The two other scenes, the origins of which are likewise unknown, show people worshiping idols - a snake and a statue of Ganesha, the Hindu god. The illustrations remain the same throughout the nineteenth century, although in the 1870s a change of printer caused some minor changes in their finer details. ${ }^{28}$

The illustrations asserted demonized ideas of the lives of people inhabiting the areas colored black: they sacrificed their children and worshiped idols. All the illustrations operated to create the spiritual distance needed to justify the need for missionary work and European presence in Asia. This idea was enforced textually in published articles. An article published in 1860, for example, included a wide-ranging discussion of the "barbarous" and "savage" traditions of the peoples in question, pointing out that the reader could see on the map one example of the "appalling crimes" committed by the "blind slaves" of idolatry: how "Chinese mothers

${ }^{25}$ Weltkarte der Mission, 1845, KARVAR-31.082, BMArchives; Selitys Lähetys-Toimen Kartalle 1878, 20-22.

${ }^{26}$ Compare Weltharte der Mission, 1845, KARVAR-31.082, BMArchives and Children's missionary map of the world, 1844, Maps CC.5.a.161, BL; Maailman kartta lähetys-toimesta, circa 1859, Map Collection of the National Library of Finland (hereafter MCNLF), Helsinki, Finland.

${ }^{27}$ The Pictorial Missionary Map of the World, 1861, Maps 950.(53.), BL. Illustrerad missions charta öfver werlden, n.d., Evang. Fosterlands Stiftelsens Förlags Expedition, n.d., UM23462, Upplandsmuseet, Uppsala, Sweden. https://digitaltmuseum.se/021025683956/skolplansch.

${ }^{28}$ The first editions were drawn by an anonymous artist at the lithographic printing house of Fredrik (Rietrikki) Polén in Helsinki. In the 1870s, they derived from Ferdinand Tilgmann's lithographic print. 
joyfully take their small babies to be buried alive". ${ }^{29}$ The illustrations thus acted as symbols of othered non-European cultures of the East: they were markers of cultural and ethnographic difference, functioning as building blocks for geographical imaginations where Asia emerged as a morally inferior space, in need of European guidance.

The two booklets - the "explanation" and the Ewankelinen Lähetysprovided by the FMS to accompany the map explained how the human geography of the world justified the expansion of missionary work. The first editions of both were published in 1859 , and the "explanation" went through fourteen editions. The Ewankelinen Lähetys was a translation from German, taken almost verbatim from a pamphlet by the Basel Mission. ${ }^{30}$ Both texts offered their readers a tour across the different lands and had a pedagogical function, familiarizing Finnish audiences with world geography. The FMS even advertised the Ewankelinen Lähetys as a geography and history lesson for ordinary Finns, who had started to enjoy slowly growing access to geography books in Finnish only since the 1840 s. $^{31}$ Together, the accompanying texts unfold as a series of ontological claims about the geographies of civility and morality: they highlight the distance between European civilizations and those of the "heathens", and proclaim the potential of various peoples for transformation.

Importantly, both texts implicitly distinguished between the expansion of the European missionary field and the formal processes of colonization; thus they informed readers of what it meant that the current expansion of European empires coincided with the expanding empire of God. This occurred especially through comments relating to the "settler revolution" underway in the British Empire, and the treatment of Indigenous peoples. ${ }^{32}$ Indeed, in Ewankelinen Lähetys, the urgent need for missionary work in Australia, New Zealand, and the rest of the Pacific Islands is explained by referring to the threat posed to the survival of Indigenous populations both by the "land-grabbing settlers from Europe" and by "the heathenish conflicts and murderous nature of the inhabitants". ${ }^{33}$ The same ideas are repeated in the "explanation": here the Europeans inhabiting New Holland are referred to as "greedy gold prospectors who 'call

\footnotetext{
29 “Heillä on silmät huoruutta täynnä,” $S L, 1860$, no 3, 42.

${ }^{30}$ See Die Evangelische Mission: Ein Ruf an Das Christenvolk 1844.

31 "Lähetys-Kirjallisuutta," SL, 1860, supplement no 1, 15; Laine 2007, 30-33.

${ }^{32}$ Belich 2009.

${ }^{33}$ Ewankelinen Lähetys 1861, 16.
} 
themselves Christians"". ${ }^{34}$ This critical stance toward settler colonialism in the Pacific and its implications for missionary work resonates with the representation of experiences derived from North America. Here the assumed inevitable disappearance of the Indigenous peoples-who are prominently identified on the map as "Indians" - is noted, but the need to convert these populations is stressed: then "they would not curse the Christians that have driven them away from their lands". ${ }^{35}$ The immorality of the "Christians in America" was further emphasized by way of notions concerning their involvement in the slave trade, the process of which was discussed at length; here Africans were portrayed both as victims of enslavement and as guilty of it themselves. ${ }^{36}$ These notions contrast with the way in which the benefits of colonial administration were portrayedand consequently justified-in India. Here colonial legislation was an ally in the battle for the progress of Christianity, in that the "missionaries have persuaded the English administration to prohibit murdering children and burning widows". ${ }^{37}$

These ideas as to the negative effects of unregulated colonial expansion within the confines of the British Empire echo British colonial philanthropic debates from the 1830s onward over the morality of colonial governance, which had popularized the idea of settlers as immoral, "aberrant Britons". ${ }^{38}$ These commentaries highlight the paradox which underpinned the remaking of global mobilities in the nineteenth century. The abolition of the slave trade and the idea of protecting Indigenous populations occurred simultaneously, as British and by extension other Europeans were encouraged to move and populate the lands that would constitute Britain's empire in North America, Australia, New Zealand, and southern Africa. ${ }^{39}$ The texts accompanying the map informed Finnish audiences about topical questions connected to European colonial expansion in their own mother tongues: forced mobilities of people and the evils of slave trade, questions of land use, and the expansion of the settler colonies. They helped their readers to view specific types of colonizers as

${ }^{34}$ Selitys Lähetys-Toimen Kartalle 1878, 13, 17.

${ }^{35}$ Ewankelinen Lähetys 1861, 27; Selitys Lähetys-Toimen Kartalle 1878, 17.

${ }^{36}$ Ewankelinen Lähetys 1861, 22-26. See Gustafsson 2003, 78-79.

${ }^{37}$ Ewankelinen Lähetys 1861, 19.

${ }^{38}$ Lambert and Lester 2004, 330. The debates culminated in the published report of the Aborigines Select Committee in 1837 which received "emblematic status" in humanitarian debates in Britain concerning colonization. Lester 2001, 105-23.

${ }^{39}$ Lester and Dussart 2014. 
reprehensible but also highlighted the support that colonial administrations could offer missionary work, for example, through legislation. Importantly, even though both the FMS and the evangelical missionary movement more broadly were critical of some of the ways in which Europeans were remaking the global space, they nevertheless considered the transformations introduced by the growing Christian empire to be justified.

\section{Constructing Colonial Spaces}

Now, dear reader, take the missionary map in your hand. Lay your eyes on the western hemisphere. All of the western parts of this half is covered in water. It is slightly bigger than the lake or river in your village. It is a grand sea. It is called Open or Still Sea ... in the middle of the wide open sea and just below the line that is drawn from the western side of the map straight to the east, and which is also called the equator, there is printed in big letters Australia. Now, if you go an inch below the letters s and t, you will come to the archipelago of Fissi. Fissi is the same as Fegee. ${ }^{40}$

In addition to the separately published booklets, the missionary maps were designed to be read together with the periodicals. On many occasions, the articles published contained explicit references to the map, instructing the reader to locate the region discussed on the map. In the above quotation, published in Suomen Lähetyssanomia in 1860, the stepby-step instructions lead the reader to the Fiji Islands. Similar references, directing the reader to fix their gaze on the space and place discussed in the article, are common in FMS periodicals, especially during the 1860s and 1870s, after which they diminish. Some of them position Finland as the area of reference, urging readers to "depart from Finland towards the southeast" or informing them that the islands of New Guinea, Greenland, or Borneo are, respectively, two, three, and four times bigger than Finland. ${ }^{41}$ These were additions that contextualized the texts for a Finnish audience and taught them to understand other regions in relation to their own sphere of life. The strong links between the periodicals and the maps

\footnotetext{
40 "Fegee luodot," SL, 1860, supplement no 5, 118. The bolding is original. The spelling of "Fissi" and "Fegee" follows the Finnish original.

41 "Borneo," SL, 1860, no 1, 10; "Weljekset lewittäwät ewankeliumia Eskimo-kansalle Gröönlannissa ja Labradorissa," SL, 1860, no 7, 104; “Uusi Guinea," SL, 1862, no 8, 125; “Taka Aasian luodot," SL, 1867, no 10, 150.
} 
was not unique to the Finnish context, but rather a typical feature of missionary periodicals; in Britain, for example, the illustrated version of the Children's missionary map of the world refers to specific volumes of the Childrens Missionary Magazine. ${ }^{42}$ Indeed, one might note that this type of publication often assumed that their readers would be able to read the texts together with the maps and vice versa.

In these moments of instructing the readers of the periodical to travel the contours of the world with the help of the map, the FMS's educational power is at its most concrete. Usually, after positioning the reader, the articles proceed to discuss the cultural practices of a particular group of people, describe their ethnic characteristics, and narrate the history of missionary work in the area. Here the map served to guide the reader, as it contained the names of certain peoples identified by Europeans: for example, "Hottentots", "Bechuans", "Kaffers", and "Namaquas" in subSaharan Africa and "Indians" in North America. In the Finnish context, many of the articles published by the FMS were either wholly or partly translations of those printed elsewhere, although the source used cannot always be directly identified. The FMS relied particularly on periodicals published by German missionary societies but also translated material from British and American periodicals as well as from colonial and British newspapers. The Finnish and Swedish versions of the FMS periodicals also translated each other's articles, and made use of material produced by Swedish missionary organizations. ${ }^{43}$

As part of the transnational missionary network which produced knowledge of the missionary field, the editors printed articles which relayed European interpretations of the meanings of colonial encounters in different parts of the world to Finnish readers. One example testifying to the FMS's channeling of colonial knowledges relates to Australia, which the British invaded and colonized during the nineteenth century. An article printed in 1861 relied on claims derived from Wesleyan and Gossner missionaries in describing the Aboriginal peoples as "stiff and stupid in their minds", since they were not receptive to God's word. The editor, Gustaf Dahlberg, explained this by noting how the "Papuas", as they referred to the inhabitants of the continent, were the "most depraved and beastly of all peoples". At the same time, the reader was informed of the colonial

\footnotetext{
${ }^{42}$ Children's missionary map of the world, 1844, Maps CC.5.a.161, BL.

${ }^{43}$ Remes 1993, 28.
} 
violence that had created hatred toward Europeans and was guided to locate some of the events described on the world map. ${ }^{44}$

The description of the challenges faced in Australia continued five years later with an account of the work of the Scot John Green, whom the Victorian government had in 1861 appointed "general inspector" to examine the condition of the Aboriginal population living within the confines of the colony. This measure followed the termination of the Aboriginal Protectorate system in the area at the end of the $1840 \mathrm{~s}$, and the recommendation issued in 1858 as to the benefits of forming reservations for the Aboriginal population. The article was a translation from the periodical published by the Berlin-based Gossner Mission; it summarized the way in which Green's position in the colony had enabled him to successfully pursue evangelical missionary work. At his Aboriginal station, Coranderrk in Healesville, Green had converted twenty-seven individuals: fields were plowed, European clothing was introduced, children were attending school, and goods were manufactured for sale to the white settlers. ${ }^{45}$ The article thus described the consequences of colonial administrative policies, which were entangled with the evangelical missionary work that Green was interested in.

The FMS's editor positioned the article as testimony to the success that persistent work would bring among even the "most wretched of all peoples", thus channeling the widely shared discourse promoting a stadial understanding of human progress. ${ }^{46}$ Ian Clark and Fred Cahir, however, note that Green's trusted position in the eyes of the Aboriginal families, especially their willingness to surrender their children to Green's care and his success in evangelical work, may have been due to their perception of Green as a black man who died but was resurrected, a ngamadjidj. The Aboriginal populations' willingness to engage with Green's preaching might thus be an indication of the reinforcement of Aboriginal cosmology, rather than their embrace of Christianity. ${ }^{47}$

Together these articles relating to Australia both contributed to the construction of an epistemology that grounded rather than disputed the colonial world order. They relied on racialized explanations to display how

\footnotetext{
44 "Weljesten menestyksestä Australiassa," $S L, 1861$, no 1, 2-8, at 8.

45 "Australia," SL, 1866, no 9, 139-41. The periodical is Die Biene auf dem Missionsfeld. For Green, see Clark and Cahir 2014, 130.

46 “Australia," SL, 1866, no 9, 139.

${ }^{47}$ Clark and Cahir 2014.
} 
differently these peoples lived, thus exploiting their otherness to evoke readers' compassion toward the "heathens". Simultaneously, they referred to the idea of a Christian family who had all been saved by Christ. ${ }^{48}$ In this assemblage of material, the map allowed the reader to cross geographical distance: first to imagine these "wretched" peoples and then to note the impact that missionary work had in advancing civilization even in the most distant parts of the Earth. In these articles, the British colonial space unfolds as a space of possibilities, provided that the evangelical missions could take the lead in intercourse with the Indigenous populations.

Another prominent form of colonial knowledges enforced by the FMS, through its world map and the texts linked to it, involved the conceptualization of geographies of cannibalism. The discourse of cannibalism formed an intrinsic part of nineteenth-century European accounts, more specifically those concerning the South Pacific. As multiple scholars have noted, this discourse is exemplary of the type of social constructions which fueled the missionary enterprise and served more generally as effective tools of European colonial projects since the conquest of South America. ${ }^{49}$ Indeed, if we return to the article on the Fiji Islands referred to in the beginning of this section, we see that after the editor has helped the reader locate the islands on the map, he then proceeds to discuss the advancement of Christianity there. According to the author, this transformation was striking, considering that the inhabitants had been known for their cruel cannibalism. Even though some rebelled against Christianity and persecuted those who had converted by burning the churches or killing people, they were a minority. The recent news from the Wesleyan missionaries had been encouraging: " 60,000 people have given up the cruelties of paganism, the filthiness and shame, and are now waiting for teachers here ... who could teach them about God's grace". ${ }^{50}$

The veracity of missionary testimony like these has been extensively debated by scholars; it is beyond the scope of the present chapter to evaluate the credibility of the multiple testimonies printed in the Finnish periodicals. ${ }^{51}$ Rather, my point here relates to the critical role played by the FMS articles, together with the world map, in spatializing cannibalism in the nineteenth century. Cannibalism was a relatively frequently revisited theme,

\footnotetext{
48 "Weljesten menestyksestä Australiassa," SL, 1861, no 1, 8.

${ }^{49}$ Brantlinger 2006; Banivanua-Mar 2010; Davies 2016.

50 "Fegee luodot," $S L, 1860$, supplement no 5, 118-19.

${ }^{51}$ See Brantlinger 2006 for a review of the debate.
} 
with multiple articles referring to the practice in different geographical contexts ranging from South America and Southeast Asia to Africa, but focusing, in particular, on the Pacific. ${ }^{52}$ The Pacific was also pinpointed as the region of cannibals in the reading materials designed to accompany the map. ${ }^{53}$ By reprinting translated articles of missionaries' "eye-witness accounts" describing the horrors they had seen or by providing Finnish audiences with "news" of missionaries killed and eaten by the cannibals here and there, the FMS taught its readers to conceptualize the world in terms of these spaces. In so doing, the FMS was continuing the ancient Western tradition, tracing back to Ptolemy's Geography, of mapping different types of "monstrosities". While the FMS map does not explicitly place cannibals anywhere specific, as was common in sixteenth-century maps, the accompanying reading materials ensured that the black spaces of the "heathens" came to be associated with cannibalism. ${ }^{54}$ By channeling knowledges which fueled geographical imaginations of barbarism and savagery, the FMS was making clear the urgency of missionary work. Simultaneously, however, the Society imposed knowledges used to justify colonial violence.

\section{Eyes on Africa}

The FMS's relationship with the geographies of the global mission field altered once it was confirmed that they could send out their first missionaries to Owambo, in present-day northern Namibia, in 1868. The missionaries had been trained in Helsinki at the missionary school which had opened in 1862. The site was chosen with the help of German missionary Carl Hugo Hahn, who had been working close by in "Hereroland" with the Rhenish Missionary Society. The Finnish presence in Owambo marked the start of complex processes of cultural changes on the ground. In

\footnotetext{
${ }^{52}$ See "Heillä on silmät huoruutta täynnä," $S L, 1860$, no 3, 42; "Ihmissyöjät Basutot," $S L$, 1866, no 12, 181-83; "Taka Aasian luodot," $S L, 1867$, no 10, 152; "Ewankeliumin julistamisesta ihmissyöjille Uusseelannissa," $S L, 1868$, no 2, 17-24; "Kuningas Thakomban ja Lähetys Fissin saarilla," SL, 1873, no 2, 24-31; "Witit (Fidschi) ennen ja nyt," $S L, 1881$, supplement no 6, 43-45; "Australian alku-asukkaat," $S L, 1881$, supplement no 7, 53-54; "Erään Bassutowaimon elämänvaiheet," $S L, 1881$, supplement no 8, 62-63; "Lähetyksestä Etelämeren saarilla," $S L, 1882$, supplement no 3, 20-21; "Kuningas Takomban Fidschisaarilla," $S L, 1884$, no 5, 72-74; "Lähetys tarpeellinen ja hedelmällinen työ," $S L 1887$, supplement no 12, 90; "Riippuwa silta Sumatran saarella," $S L$, 1890, supplement no 4, 30; “Meriroswojen keskellä Uudella Guinealla," $S L, 1892$, no 9, 138-40.

${ }^{53}$ Ewankelinen Lähetys 1861, 15-16. See Selitys Lähetys-Toimen Kartalle 1878, 19-20.

${ }^{54}$ For the early modern practices, see Van Duzer 2013, 421-29; Davies 2016.
} 
addition, the establishment and existence of Finnish missionary stations across the seas materialized in the hands of Finnish audiences as various types of maps, texts, and illustrations; these helped them navigate the distant terrain and shaped Finns' understanding of Africa more generally. The material published by the FMS differed from the type of news items already in circulation in Finland, which mainly focused on reporting the feats of European explorers and the slave trade. ${ }^{55}$ The dominance of material relating to Africa, and especially the reports of Finnish missionaries once their work started in Owambo in 1870, shadowed accounts concerning other regions of the world. They transformed the periodical in the 1870 s and 1880s into a teleport to "Ovamboland".

To enable readers to navigate Owambo, the FMS updated its cartographic materials. The new edition of the world map, published in 1871, included the significant ethnic groups and some place names. Thus, the map was transformed into a tool by means of which the reader at home could locate the overseas "outposts" and the groups of people they worked with. ${ }^{56}$ The additions included placing Walvis Bay, Cunene river, and the Rhenish missionary station Otjimbingue. Importantly, the map was filled in with the names of the Aawambo groups: the "Oukounyama", "Ongandyera", "Oukuambi", and "Ondonga". In addition, the names "Ovambo" and "Herero" were inscribed on the map. The small white dots inform the viewer as to the number of working Finnish missionary stations. ${ }^{57}$ Judging by the numbers of maps printed during the 1870 s, the establishment of the first Finnish mission increased the popularity of the world map: approximately 44,000 copies were printed, in contrast to the 26,000 printed in 1859-1869..$^{58}$ At the same time, "Ovamboland" developed into the "apple of one's eye" in Africa, as one Finnish newspaper phrased it. ${ }^{59}$

As Olli Löytty has argued, Finns participated in the Eurocentric production of "Ovamboland" as a geographical space. "Ovamboland" was a German designation, referring to the tract of land south of the Cunene River where people spoke Owambo languages; it derived from European needs and practices, rather than from the local conceptualization of

\footnotetext{
${ }^{55}$ For example, Gustafsson 2003; Groop 2018.

56 “Tillkännagifwande," $M T$, 1871, no 7, 120; “Ilmotuksia," SL, 1871, no 8, 128; Maailman kartta lähetys-toimesta, FMS, circa 1871, MCNLF.

${ }^{57}$ Selitys Lähetys-Toimen Kartalle 1878, 15.

${ }^{58}$ This estimation derives from the FMS's annual reports published in the periodicals.

59 “Tampere," Tampereen Sanomat, 5 January 1874.
} 
space. ${ }^{60}$ Indeed, when read together with the periodicals, the world map became a convenient instrument for holding the missionary field in one's hands, and linked the names of the Aawambo inscribed on the black space with existing ideas of spiritual and ethnic otherness. The editors, Gustaf Dahlberg and Klemens Sirelius, constructed articles which enforced these ideas. In 1870, for example, an article drawing heavily on a travel account by the Swedish-born explorer Charles John Anderson narrated what the Aawambo were like and how they lived. It is significant that since the excerpts derived from Anderson's account painted a relatively positive idea of these peoples, Dahlberg supplemented this with a description emphasizing their "wildness":

[E]ven though their [the Aawambo] honesty has been praised, we must remember that they are fully wild and we also want to mention that the same Anderson has during his later travels encountered these peoples many times and has fully experienced their cruelty and dishonesty as well. ${ }^{61}$

In relaying this type of description, Finns made use of the same language, especially during the early years of the mission, as that used by colonial observers in portraying African people as wild, lazy, weak, and dishonest.

Africa also became the preferred focus of illustrations. They helped imagine what Finnish work in the field would be like, for example, by showing missionaries entering an African village, an African house, or a landscape possibly like that encountered in Owambo. ${ }^{62}$ Whenever feasible, the FMS printed "accurate" images, received from the location or created by those who had returned to Finland ${ }^{63}$ In 1887, for example, the missionary Tobias Reijonen relayed an image of the mission field in Omulonga, signaling how he had "civilised" the landscape with the houses he had built during his time in Owambo in 1870-1885:

${ }^{60}$ Löytty 2006, 62-63.

61 "Owambomaa," SL, 1870, no 3, 34-41, at 40.

62 "Selitys kuwalle," $S L, 1870,33-34$; "Selitys kuwasta," $S L$, 1871, no 5, 65-66; "Selitys kuwalle," $S L, 1874$, no 6, 85-86; "Kuwa," $S L, 1876$, no 4, 61-63; “Afrikalainen kylä," $S L$, 1886, no 3, 41-42.

63 "Beskrifning till bilden," $M T, 1873$, no 8, 128; "Owambolandet," $M T, 1873$, no 12, 191; “Owambomaa," $S L, 1874$, no 1, 14-15; “Otyimbingue," $S L, 1883$, no 5, 73-75; “Afrikalaisia lapsia lähetysalaltamme," SL 1886, no 6, 87-89; "Kirkko Olundassa," SL, 1891, no $3,42-44$. 
Dear reader! When you look at this illustration ... remember that it is like a small rift in the large monstrous darkness of heathenism. ${ }^{64}$

Here Reijonen was partly channeling the iconography of the world map, which was known for its small dots of white spread across the black continents. This symbolic is known to have impacted Reijonen during his childhood, growing up in Northern Karelia, in the eastern parts of the Grand Duchy. An account of his life records the effect the map had on him:

When Tobias was young, the missionary map was published, where the heathen lands were coloured black and the Christian lands in white ... When Tobias gazed upon the map, he wept and hoped that he could do something for the beloved Saviour. It was thus he gained the desire to work as a missionary. ${ }^{65}$

To provide Finnish audiences with a more detailed understanding of the terrain that the missionaries were walking and to "awaken a love towards Africa and its black children", in 1879, the FMS published separate maps of Africa as a whole and of part of the southwestern coast. The maps were probably the work of Pietari Kurvinen, one of the first missionaries in the field, who had returned from Africa in 1875, published a fourpart book of his experiences in the field, and authored a multi-part article about Africa and the Aawambo "for the ordinary Finns". ${ }^{66}$ The maps combined information obtained on the spot and gleaned from foreign maps. ${ }^{67}$ They were bound into a tiny booklet, which explained the contents of the small foldout maps to the reader. A second edition of 5000 copies appeared only two years later in 1881, and the map continued to be sold throughout the 1880s as a useful resource in following events in the Finnish mission field. ${ }^{68}$

The maps taught people to understand the contours of the Owambo space and helped them recognize the Finnish influence there. They thus

${ }^{64}$ Tobias Reijonen, “Omulongan lähetys-asema,” $S L, 1887$, no 7, 102-4, at 104.

65 “Lähetyssaarnaaja Tobias Reijonen," Kotilähetys, 1 December 1905, 3.

${ }^{66}$ Missionskarta öfwer Afrika och Owambolandet jemte besrifning, 1879, MCNLF; Kurvinen, 1877-1880. The article was published in 1876 in SL and MT.

${ }^{67}$ Missionskarta öfwer Afrika och Owambolandet jemte besrifning, 1879, MCNLF, 3-4; Kokkonen 1993.

68 "Suomen Lähetysseuran kahdeskymmeneskolmas vuosikertomus," SL, 1881, no 8, 119; “Kirjoja myytävänä,” $S L, 1887$, no 11, 175. 
offered Finns a further means of "discovery" and "taking possession" of Africa and Owambo. Kurvinen's map of Owambo displays the toponyms that Finns inscribed on the Owambo space, that is, the missionary stations Elim, Rehoba, and Bethel, founded in the 1870s. ${ }^{69}$ The map of Africa differed in its outlook, as its purpose was to provide a general view of the continent. This did not mean depicting merely the recently discovered physical features or the toponyms. Rather, the map displayed an Africa divided according to religion into morally differentiated spaces: green coloring identified heathens, gray Muslims, and white Christians. The continent was described as "the long-forgotten, greatly spacious land savaged and demolished by slave traders, cannibals and human sacrifice". ${ }^{70}$ This description reinforced the idea given by Kurvinen in his previous writings concerning the prevalence of cannibalism in Africa, even among some of the Aawambo. ${ }^{71}$ In dividing up the continent this way, Kurvinen was following the model set by the world map and other more detailed maps available at the time, such as in Reinhold Grundemann's multivolume Allgemeiner Missions-Atlas nach Originalquellen (1867), used in Finland as well. ${ }^{72}$ Together, these resources-the updated world maps, Kurvinen's maps accompanying the texts, and the illustrations-all contributed to shaping Finnish geographical imaginations of the Owambo space and the meanings of Finnish work there.

At least in the minds of some, the Finnish presence in Africa-and the missionary project more broadly-resonated with colonialism. In 1873, soon after Finnish missionaries had entered Africa, the FMS board published a polemical text in response to a letter received from a reader of Suomen Lähetyssanomia. The author of the letter, who had signed it as "an informant of people's thoughts", criticized missionaries for robbing Native Americans of their lands and for being involved in the slave trade. Importantly, the author argued that Finnish missionaries had traveled to Africa to conquer the Owambo lands. The writer questioned the validity of choosing Africa as a site for missionary work, noting that the only reason for not choosing Russia for fieldwork must be that in Africa the

\footnotetext{
${ }^{69}$ Afrikan ja Owambomaan Lähetyskartta selityksineen, 1881, MCNLF, 21; Paunu 1909, 150,180 .

${ }^{70}$ Afrikan ja Owambomaan Lähetyskartta selityksineen, 1881, MCNLF, 6.

${ }^{71}$ Pietari Kurvinen, "Sananen Afrikasta Suomenkansalle," SL, 1876, no 8, 127-28; Pietari Kurvinen, "Nägra ord om Afrika till Finlands folk," $M T$, 1876, no 9, 142-43.

${ }^{72}$ Grundemann 1867; Missionskarta öfwer Afrika och Owambolandet jemte besrifning, 1879, MCNLF, 4 .
} 
missionaries could acquire land and power. ${ }^{73}$ It was true that Russia had been one of the original targets of the FMS, but the Tsar had prohibited these plans. ${ }^{74}$ However, as the board put it, colonizing the Owambo land "had not crossed the minds" of the missionaries, "nor had Christian missionaries anywhere taken lands or power from kings or heads of states": those criticisms applied perhaps to the Catholics and "especially to the Jesuits". Similarly, they posited that in the seventeenth century it was "Englishmen ... who acquired new homes in North America", not missionaries, who arrived later. ${ }^{75}$ This view concerning the missionaries of previous centuries coincided with the stance taken in an article on South America, published in 1868, where Portuguese and Spanish missionaries were described as ineffective due to their close connections to colonization. ${ }^{76}$ The FMS thus presented other missionaries, especially the actions of the Jesuits during the conquest of America, as reprehensible, but refused to see the evangelical mission in a similar light. The printing of sections of the letter with a detailed response to these accusations shows that the FMS was eager to dispel all rumors concerning their colonial ambitions, however marginal these rumors may have been.

\section{Conclusions}

In this chapter I have examined the mass-printed map products of the FMS, which formed the core of their promotional materials, to critically enquire how and why they enabled Finnish audiences to engage with European colonial realms. In the 1860s, before the FMS had started any work abroad, the world map, the reading materials accompanying it, and the periodicals functioned as means to publicize the diverse work that other societies had already done in different parts of the world. They taught Finns to see these areas as legitimate fields for Christian action and were designed to shape their ideas of the colonial realms. The texts guided their readers to locate different peoples on the map, and to perceive them with cultural characteristics mediated in terms of Western ideas of civility, religion, and moral codes. They communicated information about past and present power relations in colonial contexts, discussed the continuing

\footnotetext{
73 "Wastausta 'kansan ajatusten ilmoittajalle'," SL, 1873, no 2, 22-23.

${ }^{74}$ Paunu 1909, 21-22.

75 “Wastausta 'kansan ajatusten ilmoittajalle'," $S L, 1873$, no 2, 23.

76 “Intianein kääntämisestä Etelä-amerikassa,” SL, 1868, no 5, 68-74.
} 
trade of enslaved peoples, criticized the consequences of the settler expansion, and conceptualized missionary work as a separate project, in contrast to the processes of formal colonization. The FMS also participated in reproducing the discourse of cannibalism, which the maps helped spatialize in specific parts of the world, including the Finns' own area of fieldwork in Africa.

The maps provided the FMS with a powerful means to disseminate missionary imaginaries of the world, and to fuel geographical imaginations that intertwined with Finnish identity formation. The maps reinforced the arguments at the core of missionary endeavors: they served as analytical tools helping to create target communities for missionary work and aiding in conceptualizing human diversity in the world. When the editors of the periodicals of the Finnish Missionary Society directed their readers to turn their attention to the missionary map of the world while engaging with an article reporting the feats of German, English, American, and later Finnish missionaries in different parts of the world, they were simultaneously asking them to position themselves in the world. By contributing to the transnational production of hierarchical conceptualizations of "heathenism" and racialized bodies, the FMS was directly inviting their prospective audiences to imagine where they themselves fit in these hierarchies, and what this position meant. They urged Finns to take part in the transnational project of helping "Others". In so doing, they were effectively advancing a colonialist outlook on the world, by domesticating a discourse regarding many areas outside Europe as uncivil spaces in need of European-including Finnish—action.

Acknowledgments The research for this contribution has been carried out with the generous support of the Academy of Finland, grant number 331899.

\section{REFERENCES}

Ballantyne, Tony. 2007. Colonial Knowledge. In British Empire: Themes and Perspectives, ed. Sarah Stockwell, 177-197. Wiley: Blackwell.

Banivanua-Mar, Tracey. 2010. Cannibalism and Colonialism: Charting Colonies and Frontiers in Nineteenth-Century Fiji. Comparative Studies in Society and History 52 (2): 255-281.

Barringer, Terry. 2004. What Mrs Jellyby Might Have Read Missionary Periodicals: A Neglected Source. Victorian Periodicals Review 37 (4): 46-74. 
Belich, James. 2009. Replenishing the Earth: The Settler Revolution and the Rise of the Anglo-World, 1783-1939. New York: Oxford University Press.

Brantlinger, Patrick. 2006. Missionaries and Cannibals in Nineteenth-Century Fiji. History and Anthropology 17 (1): 21-38.

Brewer, Sandy. 2005. From Darkest England to the Hope of the World: Protestant Pedagogy and the Visual Culture of the London Missionary Society. Material Religion 1 (1): 98-124.

Clark, Ian D., and Fred David Cahir. 2014. John Green, Manager of Coranderrk Aboriginal Station, but Also a Ngamadjidj? New Insights into His Work with Victorian Aboriginal People in the Nineteenth Century. In Colonial Contexts and Postcolonial Theologies: Storyweaving in the Asia-Pacific, ed. J. Havea, 129-144. Palgrave Macmillan.

Davies, Surekha. 2016. Renaissance Ethnography and the Invention of the Human: New Worlds, Maps and Monsters. Cambridge: Cambridge University Press.

Die Evangelische Mission: Ein Ruf an Das Christenvolk. 1844. Basel: Schneider.

Dunch, Ryan. 2002. Beyond Cultural Imperialism: Cultural Theory, Christian Missions, and Global Modernity. History and Theory 41 (3): 301-325.

Edney, Matthew H. 2003. Bringing India to Hand. Mapping an Empire, Denying Space. In The Global Eighteenth Century, ed. Felicity Nussbaum, 65-78, 334-336. Baltimore: Johns Hopkins University Press.

Ewankelinen Lähetys: Huntawa Ääni Kristikunnalle. 1861. 2nd ed. Helsinki: Suomen Lähetysseura.

Gieseking, Jen Jack. 2017. Geographical Imagination. In International Encyclopedia of Geography: People, the Earth, Environment and Technology, ed. Douglas Richardson, Noel Castree, Mei-Po Kwan, Audrey Kobayashi, Weidong Liu, and Richard A. Marston. New York: Wiley-Blackwell and the Association of American Geographers.

Gregory, Derek. 1994. Geographical Imaginations. Cambridge, MA: Blackwell.

Groop, Kim Stefan. 2018. Exploring Africa in the Nordic Press: David Livingstone, Henry Stanley and the Popular Fascination with Exploration and Adventure in Africa in the Late 19th Century. In Modernity, Frontiers and Revolutions: Proceedings of the 4th International Multidisciplinary Congress (PHI 2018), October 3-6, 2018, S. Miguel, Azores, Portugal, ed. Maria do Rosário Monteiro and Mário S. Ming Kong, 399-405. CRC Press.

Grundemann, Reinhold. 1867. Allgemeiner Missions-Atlas Nach Originalquellen. Erste Abtheilung: Afrika. Gotha: Justus Perthes.

Gustafsson, Kalle. 2003. A Continent of Slaves: Anti-Slave Rhetoric and the Image of Africa in Finland in the Nineteenth Century. Nord Nytt 87: 69-89.

Jensz, Felicity, and Hanna Acke. 2013. The Form and Function of NineteenthCentury Missionary Periodicals: Introduction. Church History 82 (2): 368-373.

Johnston, Anna. 2005. British Missionary Publishing, Missionary Celebrity, and Empire. Nineteenth-Century Prose 32 (2): 20-43. 
Kokkonen, Pellervo. 1993. Religious and Colonial Realities: Cartography of the Finnish Mission in Ovamboland, Namibia. History in Africa 20: 155-171.

Kurvinen, P. 1877-1880. Seitsemän Ensimmäistä Vuotta Lähetyssaarnaajana Eli Iloja Sekä Suruja Afrikassa, Vibkot 1-4. Helsinki: Suomen Lähetysseura.

Laine, Päivi. 2007. Suomi Tiellä Sivistyskieleksi: Suomenkielisen Maantieteen Sanaston Kehittyminen Ja Kehittäminen 1800-Luvulla. Turku: Department of Finnish and General Linguistics of the University of Turku.

Lambert, David, and Alan Lester. 2004. Geographies of Colonial Philanthropy. Progress in Human Geography 28 (3): 320-341.

Lester, Alan. 2001. Imperial Networks: Creating Identities in Nineteenth-Century South Africa and Britain. Routledge.

Lester, Alan, and Fae Dussart. 2014. Colonization and the Origins of Humanitarian Governance: Protecting Aborigines Across the Nineteenth-Century British Empire. Cambridge: Cambridge University Press.

Löytty, Olli. 2006. Ambomaamme: Suomalaisen Lähetyskirjallisuuden Me Ja Munt. Helsinki: Vastapaino.

- 2007. Kun Ambomaa Tuli Suomeen. In Suomalaisen Arjen Historia 3: Modernin Suomen Synty, ed. Kai Häggman, 263-277. Weilin+Göös.

Lukemisia Kansan Hyödyksi. 1845. Helsinki.

Massey, Doreen B. 2005. For Space. SAGE.

Missionskartographie. 2019. Cartographica Helvetica 58: 1-71.

Nielssen, Hilde, Karina Okkenhaug, and Inger Marie Hestad Skeie. 2011. Introduction. In Protestant Missions and Local Encounters in the Nineteenth and Twentieth Centuries: Unto the Ends of the World, ed. Hilde Nielssen, Inger Marie Okkenhaug, and Karina Hestad Skeie, 1-22. Leiden: Brill.

Onnekink, David. 2020. Kingdom Come: The Eschatology of Missionary Maps. International Bulletin of Mission Research: 1-9.

Paunu, Uno. 1909. Suomen Pakanalähetystoimi II: Suomen Lähetysseura Vuosina 1859-1876. Helsinki: Suomen Lähetysseura.

Petzke, Martin. 2018. The Global Bookkeeping of Souls: Quantification and Nineteenth-Century Evangelical Missions. Social Science History 42 (2): 183-211.

Remes, Viljo. 1993. Sata Vuotta Suomalaista Lähetystyötä I:2: Siemen Kasvaa Punksi 1859-1895. Helsinki: Suomen Lähetysseura.

Said, Edward. 1993. Culture and Imperialism. New York: Vintage Books.

Selitys Lähetys-Toimen Kartalle. 1878. 11th ed. Helsinki: Suomen Lähetysseura.

Vallgårda, Karen. 2016. Were Christian Missionaries Colonizers? Reorienting the Debate and Exploring New Research Trajectories. Interventions 18 (6): 865-886.

Van Duzer, Chet. 2013. Hic Sunt Dracones: The Geography and Cartography of Monsters. In The Ashgate Research Companion to Monsters and the Monstrous, ed. Asa Simon Mittman and Peter J. Dendle, 387-435. Abingdon: Routledge. 
Open Access This chapter is licensed under the terms of the Creative Commons Attribution 4.0 International License (http://creativecommons.org/licenses/ by $/ 4.0 /)$, which permits use, sharing, adaptation, distribution and reproduction in any medium or format, as long as you give appropriate credit to the original author(s) and the source, provide a link to the Creative Commons licence and indicate if changes were made.

The images or other third party material in this chapter are included in the chapter's Creative Commons licence, unless indicated otherwise in a credit line to the material. If material is not included in the chapter's Creative Commons licence and your intended use is not permitted by statutory regulation or exceeds the permitted use, you will need to obtain permission directly from the copyright holder. 